\title{
Clinical Outcome Controversy in Helicobacter pylori Infection
}

\author{
Muhammad Miftahussurur,**, Heasty Oktaricha*, Titong Sugihartono* \\ *Division of Gastroentero-hepatology, Department of Internal Medicine \\ Faculty of Medicine, Universitas Airlangga/Dr. Soetomo General Hospital, Surabaya \\ **Institute Tropical Disease, Universitas Airlangga/Dr. Soetomo General Hospital, Surabaya
}

\begin{abstract}
Corresponding author:
Muhammad Miftahussurur. Division of Gastroentero-hepatology, Department of Internal Medicine, Dr. Soetomo General Hospital. Jl. Mayjend Prof. Dr. Moestopo No. 6-8 Surabaya Indonesia. Phone: +62-31-502-3865; Facsimile: +62-31-502-3865. E-mail:muhammad-m@fk.unair.ac.id
\end{abstract}

\begin{abstract}
H. pylori infection can manifest as intestinal and extraintestinal disease. In this review, we summarize several factors that cause differences in clinical manifestations of $\mathrm{H}$. pylori infection. Host inflammatory response and bacterial virulence are key in determining the pattern of acid secretion and gastritis. The acid level factor that has a greater effect, not H. pylori infection itself. Gastritis predominant in the gastric in the initial phase will produce higher acid and trigger gastroesophageal reflux disease (GERD). H. pylori is also the cause of gastric adenocarcinoma. Different vacA genotypes are related to the risk of clinical manifestations such as peptic ulcer or gastric cancer. However, there is variance prevalence in some countries which can be explained through a combination of several factors including age at infection, virulence factors of H. pylori, host genetic profile, and environmental factors. Besides, important differences were found at a locus in CagA H. pylori which resulted in differences in clinical outcomes in the form of gastritis or MALT lymphoma. H. pylori infection alone is not enough to trigger idiopathic thrombocytopenic purpura (ITP). Additional triggers are needed to obtain an antiplatelet autoimmune response at ITP associated with H. pylori. Therefore, the difference in clinical manifestations of $H$. pylori infection remains controversial. H. pylori is not only a single cause, but the host and environmental factors also contribute to producing different responses.
\end{abstract}

Keywords: $H$. pylori, clinical manifestations, intestinal and extraintestinal disease

\begin{abstract}
ABSTRAK
Infeksi H. pylori dapat bermanifestasi sebagai penyakit usus dan ekstraintestinal. Dalam ulasan ini, kami merangkum beberapa faktor yang menyebabkan perbedaan dalam manifestasi klinis infeksi $\mathrm{H}$. pylori. Respon inflamasi host dan virulensi bakteri adalah kunci dalam menentukan pola sekresi asam dan gastritis. Faktor kadar asam yang memiliki efek lebih besar, bukan infeksi H. pylori itu sendiri. Gastritis yang dominan di lambung pada fase awal akan menghasilkan asam yang lebih tinggi dan memicu gastroesophageal reflux disease (GERD). H. pylori juga merupakan penyebab adenokarsinoma lambung. Genotipe vacA yang berbeda berkaitan dengan risiko manifestasi klinis seperti tukak lambung atau kanker lambung. Namun, ada prevalensi varians di beberapa negara yang dapat dijelaskan melalui kombinasi beberapa faktor termasuk usia saat terinfeksi, faktor virulensi H. pylori, profil genetik inang, dan faktor lingkungan. Selain itu, perbedaan penting ditemukan di lokus di CagA H. pylori yang menghasilkan perbedaan dalam hasil klinis dalam bentuk gastritis atau limfoma MALT. Infeksi H. pylori saja tidak cukup untuk memicu idiopathic thrombocytopenic purpura (ITP). Pemicu tambahan diperlukan
\end{abstract}


untuk mendapatkan respons autoimun anti-platelet di ITP terkait dengan H. pylori. Oleh karena itu, perbedaan dalam manifestasi klinis infeksi H. pylori tetap kontroversial. H. pylori bukan hanya penyebab tunggal, tetapi faktor inang dan lingkungan juga berkontribusi untuk menghasilkan respons yang berbeda.

Kata kunci: H. pylori, manifestasi klinis, intestinal and extraintestinal disease

\section{INTRODUCTION}

Helicobacter pylori is a gram-negative spiral bacterium and include as the class I carcinogenic agent. ${ }^{1,2} \mathrm{H}$. pylori colonizes in the gastric almost $50 \%$ of the world's human population throughout their lives if not treated. The prevalence of $\mathrm{H}$. pylori infection is between $30-50 \%$ in developed countries and between $85-95 \%$ in developing countries. ${ }^{3}$ Indonesia is reported to have a low prevalence of $H$. pylori infection compared to other countries in Asia. A study of 267 patients with symptoms of dyspepsia on five major islands in Indonesia found that the prevalence of $H$. pylori infection was only $22.1 \%{ }^{4}$

H. pylori infection can manifest as intestinal and extraintestinal disease. Intestinal diseases consist of peptic ulcer, chronic gastritis, gastroesophageal reflux disease (GERD), mucosa-associated lymphoid tissue (MALT) lymphoma and gastric cancer; whereas extraintestinal diseases are related to cardiopulmonary, hematologic, metabolic, neurological and dermatological systems, also autoimmune diseases including idiopathic thrombocytopenic purpura (ITP). ${ }^{5}$ Interestingly, epidemiological data show that there are contrasts in the clinical manifestations of $\mathrm{H}$. pylori. One of the controversies is that some patients suffer from duodenal ulcer, while some others experience gastric ulcer. In addition, some patients suffer from gastroesophageal reflux disease (GERD), gastric cancer, MALT lymphoma and ITP, but others do not. In this review we summarize several factors that cause differences in clinical manifestations of $\mathrm{H}$. pylori infection.

\section{Duodenal and Gastric Ulcer}

Ulcers are characterized as lost of continuity in a portion of the walls of the digestive tract that penetrates the muscular mucosa with a diameter of at minimal 0.5 $\mathrm{cm}$, with depth to submucosa. ${ }^{6}$ Peptic ulcer consists of duodenal and gastric ulcer. Although the incidence tends to decrease, duodenal ulcer is estimated to occur in $3.5 \%$, while gastric ulcer is estimated $2.4 \%$. Duodenal ulcer is usually diagnosed in men and young age, whereas gastric ulcer occurs more often in older patients without any gender bias. ${ }^{7}$ The typical pattern of pain in duodenal ulcers is that pain occurs 90 minutes to 3 hours after eating and often disappears with antacids or food (hunger pain food relief), whereas pain in gastric ulcers is often triggered by food. ${ }^{7} \mathrm{H}$. pylori infection is related with an increased risk of peptic ulcer 3 to 4 fold and people infected with $H$. pylori will experience peptic ulcer is about $10-15 \%$ of. ${ }^{8}$

Duodenal ulcer initiated by $H$. pylori arises due to the presence of non-atrophic corpus gastritis and antralpredominant gastritis. Antral inflammation causes a decrease in somatostatin production which causes a negative feedback effect on gastrin production and results in hypergastrinemia (Figure 1A). The mechanism of decreased somatostatin secretion may include three potential mechanisms. First, antral H. pylori gastritis can change the function of gastrin and $\mathrm{D}$ cells through local production of specific cytokines. H. pylori infection causes severe antral gastritis through mucosal infiltration with acute and chronic inflammatory cells. Second, cytokines are induced by inflammation and/ or production of $\mathrm{N}$-methyl histamine, a selective $\mathrm{H} 3$ receptor agonist, by H. pylori. Gastrin, in turn, stimulates histamine secretion from Enterochromaffin-like/ECL which leads to an increase in acid secretion. Third, $H$. pylori increases the mucosal surface $\mathrm{pH}$ based on high urease activity and ammonia synthesis. Low antral $\mathrm{pH}$ is an important physiological stimulus for the synthesis and release of antral somatostatin. ${ }^{8}$ So therefore, $H$. pylori should not be able to colonize the normal duodenum because it is inhibited by bile, can colonize due to the presence of gastric metaplasia that causes inflammation and ulceration. ${ }^{7,9}$

In gastric ulcer, acid hypersecretion lasts about 8 weeks and is caused by an increase in parietal cell mass and hypergastrinemia-induced ECL causing the gastric to respond with inflammation by reducing somatostatin levels, thereby releasing inhibition of $\mathrm{G}$ cells and parietal cells to maximize gastric acid output. Over time, predominant corpus gastritis in chronically infected patients reduces the amount of acid and causes atrophy of the glands of the specks with loss of parietal cells. Resulting irreversible achlorhydria and is associated with gastric ulcers (Figure 1B). The 


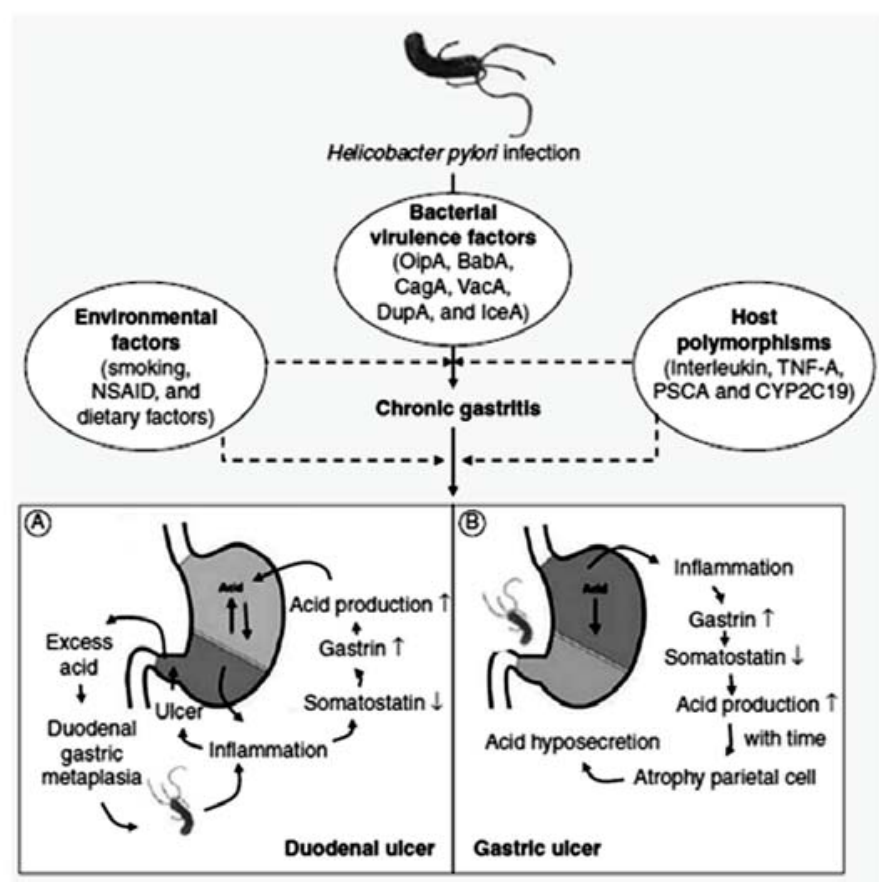

Figure 1. The opposite end of the peptic ulcer disease spectrum

process of peptic ulcers is generally observed in the transition zone between the antrum and the corpus in the minor curvatura, which may be related to severe colonization and due to marked inflammation and epithelial damage and to ulceration. It is not clear why H. pylori-induced inflammation has a pre-dominant pattern of pan-gastritis or corpus in some people, but antral predominance in others. One possibility is that it occurs similar to autoimmune gastritis caused by an immune effector with specificity for proton pump ATPase in the gastric. Interestingly, the involvement of acidity is supported by the observation that long-term gastric acid inhibition can result in a shift from antralpredominant to corpus-predominant inflammation. ${ }^{7,8}$

Genetic polymorphisms in conjunction to bacteria and/or environmental factors. Duodenal ulcer is related with high acid secretion and high antral inflammation (A). Gastric ulcer related with pan gastritis or corporal gastritis and decreased or normal acid secretion (B). ${ }^{8}$

Host inflammatory response and bacterial virulence are key in determining the pattern of acid secretion and gastritis. East Asian CagA-positive strains can mainly induce corpus pangastritis or predominant gastritis with hypochlorhidria. ${ }^{9}$ Likewise strains with long intact dupA are related with an increased risk of gastric ulcer. Whereas patients infected with oipA strains, 12-bp cagA insertions, vacA $d 1$ and $\operatorname{dup} A$ have a significant increased risk of duodenal ulcer (Table 1). ${ }^{8}$ Hosts with the $I L-1 B-511 \mathrm{~T} / \mathrm{T}$ allele had a significantly duodenal ulcer, whereas $I L-10-592-\mathrm{A} / \mathrm{A}$ had a significantly higher frequency in gastric ulcer patients. ${ }^{8}$
Table 1. Outline of the relationship between host genetic polymorphism, bacterial virulence genes and peptic ulcer ${ }^{8}$

\begin{tabular}{lccc}
\hline \multicolumn{1}{c}{ Gen } & Region & $\begin{array}{c}\text { Gastric } \\
\text { ulcer }\end{array}$ & $\begin{array}{c}\text { Duodenal } \\
\text { ulcer }\end{array}$ \\
\hline Host factors & Western & $\uparrow$ & $\uparrow$ \\
TNF-A-238 G/A & Western & $\uparrow$ & $\uparrow$ \\
TNF-A-308 G/A & Western & $\uparrow$ & $\uparrow$ \\
TNF-A-857 T/T & Asian & $\uparrow$ & $\uparrow$ \\
TNF-A-863 A carriers & Asian & $\uparrow$ & $\uparrow$ \\
TNF-A-1031 C & Asian & $\uparrow$ & $\uparrow$ \\
carriers & Asian & & $\uparrow$ \\
IL -1B-31 C/C & Asian & $\uparrow$ & $\uparrow$ \\
IL -1B-511 T/T & Asian & $\uparrow$ & $\uparrow$ \\
IL -1B-31 C/C & Asian & $\uparrow$ & $\uparrow$ \\
IL -1 RN*2/*2 & Asian & $\uparrow$ & $\uparrow$ \\
IL -6-572 G/G & South American & $\uparrow$ & $\uparrow$ \\
IL -8-251 A/A & Asian & $\uparrow$ & \\
IL -10-819 T carriers & Western & $\uparrow$ & $\uparrow$ \\
IL -10-592 A/A & Asian & $\uparrow$ & $\uparrow$ \\
CYP2C19 URM & Asian & $\uparrow$ & $\uparrow$ \\
CYP2c19 RM & &
\end{tabular}

carriers

Bacterial virulence

oipA

babA

$\operatorname{cag} A$

12-bp insertion cagA cagA tipe Asia Timur $\operatorname{vac} A \mathrm{~s} 1 \mathrm{~m} 1$

$\operatorname{vacA}$ i1

$\operatorname{vac} A \mathrm{~d} 1$

dupA

intact long type dupA

iceA1

Asia and Western
Western
Asian and Western
Asian
Asian
Asian and Western
Asian and Western
Asian
Asian
Asian

$\begin{array}{cc} & \uparrow \\ \uparrow & \uparrow \\ \uparrow & \uparrow \\ \uparrow & \uparrow \\ \uparrow & \uparrow \\ \uparrow & \uparrow \\ & \uparrow \\ & \uparrow \\ \uparrow & \\ \uparrow & \uparrow\end{array}$

TNF: tumour necrosis factor; IL: interleukin; CagA: cytotoxin-associated gene $A$; oipA: outer inflammatory protein $A$; dupA: duodenal ulcer promoting gene a; URM: ultra-rapid metabolizers; RM: rapid metabolizers, vacA: vacuolating cytotoxin gene $\mathrm{A}$

\section{Gastroesophageal Reflux Disease (GERD) and non GERD}

GERD is a condition in which there is gastric reflux that expose the contents of the gastric to the esophageal squamous epithelium. Reflux disease is characterized 
into GERD and non-erosive reflux disease (NERD)..$^{10}$ Interestingly, H. pylori infection is lower in developed countries such as North America, Western Europe and Australia, while GERD and its complications are more common in these countries. In contrast, the frequency of $H$. pylori infection is higher in developing countries such as South America, Eastern Europe, Africa, China and India while GERD and its severity are lower in these countries. ${ }^{11}$

The existence of the negative correlation between the prevalence of GERD with $H$. pylori infection raises the suspicion that $H$. pylori has a protective effect to prevent the occurrence of GERD. It is also supported that patients with $H$. pylori-positive peptic ulcers are more likely to develop GERD than patients with $H$. pylorinegative gastric ulcers. ${ }^{12}$ But after further analysis, the acid level factor that has a greater effect, not $H$. pylori infection itself. Gastritis predominant in the gastric in the initial phase will produce higher acid and trigger GERD. Whereas gastritis with antrum predominance has lower acid levels, thus, the risk of GERD is lower. ${ }^{10}$

The genetic polymorphisms of IL-1B and IL$1 \mathrm{RN}$ are inversely proportional to the risk of GERD in $H$. pylori-infected subjects because their specific genotypes are related to gastric cancer, hypochlorhidria and corpus atrophy. ${ }^{911}$ Thus, these specific genotypes, including the IL-1RN-1, IL-1B-511-T, and IL-1B-31-C allele, can be considered protective against GERD. Specifically, subjects with IL-1B-511 T alleles were emphasized in the presence of $H$. pylori infection due to high gastric mucosal IL-1 $\beta$ levels. However, other researchers have reported conflicting results that the IL-1B-511-T allele is related with reflux oesophagitis..$^{9,11} \mathrm{~A}$ few genetic risk factors for GERD, including polymorphisms in the G-protein beta 3 (GNB3) subunit, glutathione S-transferase P1, IL-10, CYP2C19, DNA repair genes and cyclin D1, may be involved. The interaction between the virulence of $H$. pylori infection and genetic factors may be the cause for the low prevalence of GERD in Asian states., ${ }^{911}$

\section{Gastric Cancer and Non Gastric Cancer}

H. pylori is the cause of gastric adenocarcinoma. Gastric adenocarcinoma is divided into intestinal and diffuse subtypes. The sequence of pathological changes leading to intestinal type cancer starting with chronic gastritis, followed by gastric atrophy and continues to intestinal metaplasia, dysplasia, and finally carcinoma. ${ }^{13}$ There were 21,000 new cases of gastric cancer in the United States and 10,570 Americans died in $2010 .^{1}$
Interestingly, there is a population infected with $H$. pylori in Africa by $91 \%$, but has a very low prevalence of gastric cancer. Similar patterns are reported in South Asian countries such as India and Bangladesh. In contrast, in East Asian countries such as Japan, China and Korea; there is a positive relationship between the prevalence of gastric cancer and $H$. pylori infection. This variance can be explained through a combination of several factors including age at infection, virulence factors of $H$. pylori (Table 2), host genetic profile and environmental factors. ${ }^{14}$

CagA protein is injected into the host cell via T4SS. In both humans and animals, CagA expression is related to the host's inflammatory response and increases the risk of developing mucosal ulcer and atrophy. The presence of CagA-positive increases the risk of developing gastric cancer by about 2 -fold. Whereas gastritis, peptic ulcer and gastric cancer also occur in CagA-negative H. pylori infection. It can be explained that infection with CagA-positive strains is associated with increased IL-8 production. In vitro experiments also showed epithelial cells infected with CagA-positive $H$. pylori producing elongation and spread of epithelial cells, referred to as the 'hummingbird phenotype'. In vivo studies of a number of different experiments in experimental animals have shown that CagA-positive infection is associated with increased gastric mucosal inflammation. ${ }^{2}$

The CagA protein subtype is based on the presence of the Glu-Pro-Ile-Tyr-Ala motif (EPIYA). Variations in amino acid sequences consist of EPIYA motifs that identify 4 subtypes, namely APIYA-A, EPIYA-B, EPIYA-C and EPIYA-D followed by CagA which are separated into Western-types (ABC, $A B C C$, $\mathrm{ABCCC}$ ) or East-Asian type (ABD). East-Asian-type CagA showed stronger in vitro affinity ties to the $\mathrm{Src}$ homology 2 domain from Src homology 2 containing protein-thyrosine phosphatase (SHP2) as well as a better ability to induce the hummingbird phenotype compared to Western-type CagA. Both types are associated with greater mucosal inflammation than CagA-negative infections. H. pylori East-Asian type CagA is also associated with greater mucosal inflammation than infection with Western-type CagA. ${ }^{2}$ Thus, patients infected with $H$. pylori CagA positive and East-Asian type CagA tend to have a higher risk of developing gastric cancer than the negative one.

VacA was recognized as vacuolating cytotoxin, functioning vacuation of epithelial cells in vitro. VacA have multiple functions, including initiation of infection, lymphocyte modulation, changing 
membrane permeability in mammalian epithelial cells. ${ }^{2}$ Different $v a c A$ genotypes are related with the risk of clinical manifestations such as peptic ulcer or gastric cancer. Genes are divided into two types based on differences in the signal and middle regions (ie types tipe $\mathrm{s}$ 'and' $\mathrm{m}$ '). The vacA s1m1 genotype is related with the most cytotoxic strain and is associated with an increased risk of gastric cancer. This is supported by the relationship between the vacA s $1 \mathrm{~m} 1$ genotype and peptic ulcer or gastric carcinoma in the Middle East, Latin America, and several African states. ${ }^{15}$ Studies in Spain report that strains of vacA $\mathrm{s} 1$ and $\mathrm{m} 1$ tend to develop preneoplastic gastric lesions. In the Portuguese population, $\mathrm{s} 1 \mathrm{~m} 1$ is related with an increased risk of gastric carcinoma. ${ }^{2}$

The outer inflammatory protein (OipA) is associated with increased inflammation and involves the production of IL-8 in the gastric mucosa via interplay with AP-1, nuclear factor-kappaB $(\mathrm{NF}-\kappa \mathrm{B})$ transcription factors and ISRE-like elements. OipA's ability to increase NF$\kappa \mathrm{B}$ activity is an independent PAI cag. A study shows that oipA 'on' shows a significant relationship with an increased risk of peptic ulcer and gastric cancer. ${ }^{2}$ The representation of the antigen-binding adhesin (BabA) blood group, which adheres to monofucosilat (ABO) and diphosylate (Lewisb) can be thought of as determining the solidity of $H$. pylori colonization. In humans, a BabA-positive strain is related with a 2-fold increase in gastric atrophy compared to BabA-negative strain infection. This surveillance is appropriate with studies that show that BabA-positive strains colony are denser and create more IL- 8 secretion in the mucosa than BabA-negative strains. It is crucial to note that CagA, BabA and OipA can be expressed together. ${ }^{2}$

The low fiber diet or high salt, N-nitroso compounds from diet or smoking, alcohol consumption, low socioeconomic status, obesity, old age and previous gastric surgery are associated with increased gastric cancer. ${ }^{13,14}$ Salt and $H$. pylori have a synergistic effect that salt damages the gastric mucosa which allows infection and persistence of $\mathrm{H}$. pylori, increasing susceptibility to tumorigenesis. ${ }^{14}$ The nitrate diet is reduced to nitrite by the mouth and gastric flora at high $\mathrm{pH}$ and subsequently responds with amines and is turned to carcinogens. The amount of salivary nitrates and nitrites is positively associated with the high prevalence of gastric cancer in endemic areas in other states. ${ }^{16}$

\section{Mucosa-associated Lymphoid Tissue (MALT) Lymphoma and non MALT Lymphoma}

Primary gastric lymphoma is the most common extranodal site of non-Hodgkin's lymphoma and ranges from $30 \%$ to $40 \%$ of all extranodal lymphomas. It also represents $4 \%$ to $20 \%$ of all non-Hodgkin's lymphomas and about $5 \%$ of primary gastric neoplasms. The frequent histological subtype in primary gastric lymphoma is marginal B cell zone lymphoma of MALT lymphoma. ${ }^{17}$ The incidence of development of primary gastric lymphoma is 2-3 times higher in men than women. ${ }^{17}$ Clinical manifestations vary from nausea, vomiting, dyspepsia, epigastric pain to massive bleeding, chronic gastric bleeding with iron deficiency anemia, pyloric stenosis, and weight loss. ${ }^{17}$

MALT gastric lymphoma is very strongly related with $H$. pylori infection. During H. pylori infection, normal $\mathrm{B}$ cells are transformed into malignant clones through three translocations of chromosomes $\mathrm{t}$ (11; 18) (q21; q21), t $(1 ; 14)(\mathrm{p} 22 ; \mathrm{q} 32)$ and $\mathrm{t}(14 ; 18)$ (q32; q21), results in the activation of kappa B nuclear factor (NF- $\mathrm{kB})$, which acts in inflammation, apoptosis and immunity. Studies show that $\mathrm{t}(11 ; 18)(\mathrm{q} 21 ; \mathrm{q} 21)$ is found more frequently in patients with a CagApositive $H$. pylori strain that determines occurrence of MALT lymphoma. However, conventional cagA and $v a c A$ genotypes did not show a significant difference between gastric cancer and MALT lymphoma. Further analysis of complete sequences of protein from CagA and VacA could recognize four loci in CagA, and three loci in VacA that could potentially cause MALT lymphoma or gastric cancer in the long term. Important differences were found at a locus in CagA H. pylori which resulted in differences in clinical outcomes in the form of gastritis or MALT lymphoma. In addition, a locus was found in VacA which caused a difference between gastritis and gastric cancer. ${ }^{18}$

Table 2. Putative virulence factors that may be associated to clinical manifestations ${ }^{2}$

\begin{tabular}{|c|c|c|c|}
\hline \multirow{2}{*}{ Gene or region } & \multirow{2}{*}{ Protein } & \multicolumn{2}{|c|}{ H. pylori virulence genes type } \\
\hline & & High virulent & Less virulent \\
\hline $\begin{array}{l}\text { cag PAl } \\
\text { cagA }\end{array}$ & $\begin{array}{c}\text { CagA dan T4SS } \\
\text { CagA }\end{array}$ & Complete & $\begin{array}{l}\text { Incomplete or absent } \\
\text { Negative }\end{array}$ \\
\hline & & East-Asian type CagA & Western-type CagA \\
\hline & & Multiple repeats (e.g. ABCC, ABCCC, ABBD) & Single repeat \\
\hline vacA & VacA & $\mathrm{s} 1, \mathrm{~m} 1, \mathrm{i} 1, \mathrm{~d} 1 \mathrm{forms}$ & $\mathrm{s} 2, \mathrm{~m} 2, \mathrm{c} 2, \mathrm{~d} 2$ forms \\
\hline babA & BabA & Present & Absent \\
\hline oipA & OipA & On & Off \\
\hline
\end{tabular}

CagA: cytotoxin-associated gene $\mathrm{A}$; oipA: outer inflammatory protein $\mathrm{A}$ 
Other studies show patients with MALT lymphoma have a high prevalence of Human Leucoyte Antigen (HLA)-DQA1*0103, HLA-DQB1*0601 and R702W mutations in the NOD2/CARD15 gene. ${ }^{17}$

\section{Idiopathic thrombocytopenic purpura (ITP) and non ITP}

ITP is defined as an autoimmune disorder characterized by immunologic destruction of normal platelets. H. pylori infection is a secondary cause of ITP. ${ }^{19,20}$ The prevalence of $H$. pylori infection in patients with ITP is higher than healthy individuals of the same age group and gender. ${ }^{19}$ At least $70 \%$ of cases diagnosed in childhood will heal fully within six months, even no treatment. One third of the remaining chronic cases will fully recover during the follow-up period, another third will only finish with mild thrombocytopenia. Thrombocytopenia purpura is usually prolonged in adults and the chance of complete remission is $20-40 .{ }^{21}$

Several authors have looked for differences in hereditary factors in ITP patients with or without H. pylori infection. Several studies examined HLADQB1 and DRB1 alleles in Italian patients with ITP and found that $H$. pylori-positive patients had higher DRB1*11 frequencies, DRB1*14, and DQB1*03, and lower DRB $1 * 03$ frequencies, compared with $H$. pylori-negative patients. Nevertheless, several studies unsuccessfull to find an relationship between $H$. pylori infection and HLA-DQB1 or DRB1alleles in Japanese patients with ITP. Gene polymorphisms in the IL-1 $\beta$ are related with $H$. pylori infection in patients diagnosed before 50 years old. ${ }^{19,22}$ In addition, there were no differences in serum IL-2, IL-4, or IL-6 levels in patients with and without $H$. pylori infection. Serum chemokine levels, including monocyte chemoattractant protein-1, are regulated in the activation of T cells that are normally expressed and secreted, and epithelial cell-derived neutrophil attractant-78, are significantly higher in patients with $H$. pylori infection compared to negative, although this increase in chemokine levels was also monitored in individuals who had digestive disorders associated with $H$. pylori but did not have ITP. ${ }^{19}$

One interesting hypothesis is the theory of molecular mimicry with the production of cross-reactive antibodies that respond on $H$. pylori components and platelet surface antigens. Several studies have shown that eluted platelets in $H$. pylori-infected ITP patients recognize CagA protein in immunoblots, but unrecognized in non-ITP-infected $H$. pylori patients. ${ }^{23}$ One study even reported that monoclonal antibodies produced for $\mathrm{H}$. pylori urease $\mathrm{B}$ respond with GP IIb/IIIa expressed on the platelet surface. ${ }^{24}$ In other potential mechanism, $H$. pylori infection can change the balance of $\mathrm{Fc} \gamma$ receptors from monocytes/ macrophages and lead the formation of autoantibodies. A study represented that the expression of Fc $\gamma \mathrm{R}$ II B in circulating monocytes was downregulated in ITP patients infected with $H$. pylori. Therefore, H. pylori can change the balance of $\mathrm{Fc} \gamma$ receptors from monocytes/ macrophages through downregulation of Fc $\gamma \mathrm{R}$ II B receptor inhibitors. ${ }^{19,25}$ In addition, some strains of $H$. pylori cause platelet aggregation that depends on the interaction of von Willebrand factor and IgG antibodies for $H$. pylori with the appropriate receptors, GP Ib and FcyR IIA, on platelets. In this model, anti-H. pylori antibodies can operate on platelets by binding to $H$. pylori, von Willebrand factor, and GP Ib, such as antiplatelet autoantibodies. H. pylori infection alone is not enough to trigger ITP. Additional triggers are needed to obtain an anti-platelet autoimmune response at ITP associated with $\mathrm{H}$. pylori. ${ }^{19}$

Several studies reported an association in 1998 that there was a significant increase in platelets in ITP patients after eradication of $H$. pylori. ${ }^{19,22}$ This effect is present in the next few reports and is summarized in a systematic review of 24 observational studies and 1 control study involving 1,555 patients. Several studies have found that $50 \%$ of adults have an increased platelet response after $H$. pylori eradication therapy, especially in those with mild ITP. A systematic review of 11 controlled studies obtained platelet count responses in $51 \%$ of patients infected with $H$. pylori versus an $8.8 \%$ increase in platelets in negative control $H$. pylori, which further strengthened the causal relationship. In a follow-up study 8 years after eradication therapy, no recurrence occurred. ${ }^{19}$

\section{CONCLUSION}

The difference in clinical manifestations of $H$. pylori infection remains controversial. $H$. pylori is not only a single cause, but host and environmental factors also contribute to produce different responses.

\section{ACKNOWLEDGMENT}

This study was funded by grants from Penelitian Skema Penelitian Dasar in 2020, Ministry of research, Technology and Higher Education of the Republic of Indonesia (584/UN3.14/PT/2020). 


\section{REFERENCES}

1. Longo DL, Fauci AS. Harrison gastroenterology and hepatology 2013;2:279-85.

2. Miftahussurur M, Yamaoka Y, Graham DY. Helicobacter pylori as an oncogenic pathogen, revisited. Expert Rev Mol Med 2017;19:1-11.

3. Khoder G, Sualeh Muhammad J, Mahmoud I, Soliman SSM, Burucoa C. Prevalence of Helicobacter pylori and its associated factors among healthy asymptomatic residents in the united arab emirates. Pathogens 2019;8:44.

4. Syam AF, Miftahussurur M, Makmun D, Nusi IA, Zain LH, Zulkhairi, et al. Risk factors and prevalence of Helicobacter pylori in five largest islands of Indonesia: A preliminary study. PLoS One 2015;10:1-14.

5. Wroblewski LE, Peek RM, Wilson KT. Helicobacter pylori and gastric cancer: Factors that modulate disease risk. Clin Microbiol Rev 2010;23:713-39.

6. Kusters JG, van Vliet AHM, Kuipers EJ. Pathogenesis of Helicobacter pylori infection. Clin Microbiol Rev 2006;19:449-90.

7. Bebb J. Helicobacter pylori infection and peptic ulcers Key points. Medicine (Baltimore) 2019;1-9.

8. Miftahussurur M, Yamaoka Y. Helicobacter pylori virulence genes and host genetic polymorphisms as risk factors for peptic ulcer disease. Expert Rev Gastroenterol Hepatol 2015;9:1535.

9. Hong SJ, Kim SW. Helicobacter pylori infection in gastroesophageal reflux disease in the Asian countries. Gastroenterol Res Pract 2015;2015.

10. Miftahussurur M, Doohan D, Nusi IA, Adi P, Rezkitha YA, Waskito LA, et al. Gastroesophageal reflux disease in an area with low Helicobacter pylori infection prevalence. PLoS One 2018;13(11).

11. Ghoshal UC, Chourasia D. Gastroesophageal Reflux Disease and : What May Be the Relationship? J Neurogastroenterol Motil 2010;16:243-50.

12. Jie W, Qinghong X, Zhitao C. Association of Helicobacter pylori infection with gastroesophageal reflux disease. $\mathrm{J}$ Int Med Res 2019;47:748-53.

13. Testerman TL, Morris J. Beyond the stomach: An updated view of Helicobacter pylori pathogenesis, diagnosis, and treatment. World J Gastroenterol 2014;20:12781-808.

14. Ishaq S, Nunn L. Helicobacter pylori and gastric cancer: A state of the art review. Gastroenterol Hepatol from Bed to Bench 2015;8:S6-14.

15. Sugimoto M, Yamaoka Y. The association of vacA genotype and Helicobacter pylori-related disease in Latin American and African populations. Clin Microbiol Infect 2009;15:835-42.

16. Mitacek EJ, Brunnemann KD, Suttajit M, Caplan LS, Gagna $\mathrm{CE}$, Bhothisuwan K, et al. Geographic distribution of liver and stomach cancers in thailand in relation to estimated dietary intake of nitrate, nitrite, and nitrosodimethylamine. Nutr Cancer 2008;60:196-203.

17. Violeta Filip P, Cuciureanu D, Sorina Diaconu L, Maria Vladareanu A, Silvia Pop C. MALT lymphoma: epidemiology, clinical diagnosis and treatment. J Med Life 2018;11:187-93.

18. Hashinaga M, Suzuki R, Akada J, Matsumoto T, Kido Y, Okimoto T, et al. Differences in amino acid frequency in CagA and VacA sequences of Helicobacter pylori distinguish gastric cancer from gastric MALT lymphoma. Gut Pathog 2016;8:1-10.
19. Kuwana M. Helicobacter pylori -associated immune thrombocytopenia: Clinical features and pathogenic mechanisms. World J Gastroenterol 2014;20:714-23.

20. Sheema K, Ikramdin U, Arshi N, Farah N, Imran S. Role of Helicobacter pylori Eradication Therapy on Platelet Recovery in Chronic Immune Thrombocytopenic Purpura. Gastroenterol Res Pract 2017;2017.

21. Aljarad S, Alhamid A, Sankari Tarabishi A, Suliman A, Aljarad Z. Correction to: The impact of helicobacter pylori eradication on platelet counts of adult patients with idiopathic thrombocytopenic purpura. BMC Hematol 2019;19:1-8.

22. Papagiannakis $\mathrm{P}$, Michalopoulos C, Papalexi F, Dalampoura $\mathrm{D}$, Diamantidis MD. The role of Helicobacter pylori infection in hematological disorders. Eur J Intern Med 2013;24:685-90.

23. Takahashi T, Yujiri T, Shinohara K, Inoue Y, Sato Y, Fujii Y, et al. Molecular mimicry by Helicobacter pylori CagA protein may be involved in the pathogenesis of $\mathrm{H}$. pylori-associated chronic idiopathic thrombocytopenic purpura. Br J Haematol 2004;124:91-6.

24. Bai Y, Wang Z, Bai X, Yu Z, Cao L, Zhang W, et al. Crossreaction of antibody against Helicobacter pylori urease B with platelet glycoprotein IIIa and its significance in the pathogenesis of immune thrombocytopenic purpura. Int $\mathrm{J}$ Hematol 2009;89:142-9.

25. Tsay F, Hsu P. H . pylori infection and extra-gastroduodenal diseases $2018 ; 1-8$. 